\title{
SEMIPURIFIKASI DAN KARAKTERISASI KOLAGENASE DARI ORGAN DALAM IKAN BANDENG (Channos channos, Forskal) ${ }^{1}$
}

\author{
Oleh \\ Tatty Yuniarti², Tati Nurhayati ${ }^{3}$, Agoes M. Jacoeb ${ }^{3}$
}

\begin{abstract}
Abstrak
Aktivitas enzim-enzim proteolisis seperti kolagenase, dapat memecah protein menjadi molekul yang lebih sederhana (autolisis) mengakibatkan terjadinya pelemasan daging ikan pada fase post mortem. Penelitian perlu dilakukan untuk mengetahui sifat-sifat enzim tersebut. Tujuan dari penelitian ini adalah untuk memurnikan dan mengkarakterisasi enzim kolagense dari organ dalam bandeng. Enzim kolagenase telah dapat dimurnikan dari organ dalam bandeng (Chanos chanos, Forskal), dengan ekstraksi dan pengendapan menggunakan ammonium sulfat. Tingkat kelipatan pemurnian yang dihasilkan 2,347 dan yield adalah 35,42. Karakterisasi kolagenase menunjukkan suhu optimum $50{ }^{\circ} \mathrm{C}$ dan $\mathrm{pH}$ optimum 8-9. Enzim kolagenase dapat dihambat dengan kuat oleh serine proteinase inhibitor (PMSF)dan meningkat aktivitasnya dengan penambahan $\mathrm{Ca}^{2+}$ dan $\mathrm{Na}^{+}$, enzim kolagenase ini stabil pada $10-50{ }^{\circ} \mathrm{C}$ and $\mathrm{pH} 8-9$.
\end{abstract}

Kata kunci : kalogenase, karakterisasi, semifuripikasi, organ dalam bandeng.

\footnotetext{
${ }^{1}$ Tulisan ini adalah bagian dari tesis atas nama Tatty Yuniarti dari Mayor Teknologi Hasil Perairan, IPB

2 Jurusan Penyuluhan Perikanan, STP

${ }^{3}$ Departemen Teknologi Hasil Perairan, IPB
} 


\section{PENDAHULUAN}

Ikan bandeng (Chanos chanos, Forskal) merupakan spesies penting dalam perikanan budidaya di Indonesia. Ikan bandeng menjadi salah satu produk yang mendominasi produksi perikanan budidaya yaitu sebesar 269.530 ton dari total produksi perikanan budidaya, yaitu sebesar 2.625.800 ton (Ditjen Perikanan Budidaya 2007). Kandungan gizi ikan bandeng dalam $85 \mathrm{~g}$ yaitu protein $17 \mathrm{~g}$, lemak $5,7 \mathrm{~g}$ dan karbohidrat 0,0 g. Selain itu, ikan bandeng juga kaya akan mineral seperti Fe, $\mathrm{Ca}, \mathrm{P}, \mathrm{Mg}$ dan $\mathrm{K}$, serta vitamin $\mathrm{A}$ dan $\mathrm{B}$ kompleks (USDA SR-21 2009).

Kandungan gizi ikan bandeng menjadi tidak bernilai tinggi apabila tidak ditangani dengan baik setelah penangkapan atau pemanenan. Hal ini disebabkan ikan bandeng sebagai bahan pangan ikani sangat rentan terhadap kerusakan (highly perishabe food). Kerusakan ini dapat terjadi secara fisik, biokimiawi maupun mikrobiologi. Kerusakan daging ikan yang terjadi pada fase rigor mortis dan diakhiri pada fase post rigor, ditandai dengan melemasnya daging ikan (softening). Pelemasan ini bukan disebabkan oleh terpecahnya protein aktomiosin yang telah terbentuk tetapi karena kerusakan jaringan daging ikan. Kerusakan ini disebabkan oleh aktivitas enzim-enzim proteolisis yang memecah protein menjadi molekul yang lebih sederhana (autolisis) (Clucas dan Ward 1996).

Enzim-enzim proteolisis mampu menghidrolisis protein pada daging ikan. Enzim-enzim tersebut antara lain kolagenase, katepsin dan kalpain. Aktivitas kolagenase menyebabkan terjadinya keadaan yang tidak diinginkan, yaitu terpisahnya jaringan ikat daging ikan (gaping) (Hultman 2003). Hultman dan Rustrad (2004) menyatakan bahwa enzim endogeneus kolagenase mempengaruhi perubahan tekstur daging ikan (fillet) Atlantic salmon (Salmo salar) pada fase post mortem.

Aktivitas kolagenase tertinggi dari ikan bandeng terdapat pada fase pos rigor (Fentiana 2009). Ekstrak kasar kolagenase dari usus diketahui mengandung aktivitas kolagenase yang lebih tinggi, dibandingkan organ dalam yang lain (Yuniarti et al. 2010). Akan tetapi kolagenase yang lebih dimurnikan belum diketahui sifat karakteristiknya. Sifat-sifat kolagenase dari ikan bandeng penting diketahui agar dapat dihindari kondisi yang tidak 
diinginkan. Kolagenase dari ikan bandeng dapat digunakan sebagai alternatif sumber enzim baru, sebab sumber-sumber enzim baru masih diperlukan (BPPT 2003). Kolagenase sebagai salah satu produk bioteknologi dapat dimanfaatkan dalam berbagai bidang. Kolagenase telah digunakan dalam perbaikan radang pada jaringan, transplantasi klinis, fungsi seluler dalam penggumpalan darah, fibrinolisis dan fertilisasi (Simpson 2000) dan mempercepat proses penyembuhan luka (Rilley dan Herman 2005). Kolagenase dari hepatopankreas kepiting telah digunakan untuk deskinning pada cumi-cumi (Lopez dan Carreno 2000).

Penelitian ini bertujuan untuk memurnikan kolagenase hingga tahap pemurnian yang biasa digunakan dalam industri yaitu pengendapan menggunakan ammonium sulfat dan melakukan karakterisasi kolagenase dari usus ikan bandeng. Penelitian ini bermanfaat untuk mendapatkan informasi sehingga dapat mengaplikasikan kolagenase sesuai dengan sifat dan karakterisasinya tersebut dan memanfaatkan organ dalam ikan bandeng sebagai alternatif sumber kolagenase.

\section{METODOLOGI}

Penelitian dilaksanakan pada Desember 2008 sampai dengan November 2009. Ikan bandeng diperoleh dari tambak di desa Dadap, Tangerang. Penelitian bertempat di Laboratorium Mikrobiologi dan Biokimia Hasil Perairan, Departemen THP; Laboratorium Prolink, MSP, FPIK; Laboratorium Penyakit Hewan, FKH; dan Laboratorium Bioteknologi, Pusat Penelitian Sumberdaya Hayati dan Bioteknologi, Lembaga Penelitian dan Pemberdayaan Masyarakat, IPB.

\section{Tahap-tahap Penelitian}

Semi purifikasi kolagenase dilakukan dalam tiga tahap tahap, yaitu preparasi organ dalam, ekstraksi dan pengendapan. Karakterisasi kolagenase meliputi penentuan kondisi optimum enzim koalgenase. Ditentukan juga kestabilan kolagenase terhadap suhu dan $\mathrm{pH}$.

Organ dalam bandeng dipisahkan bagian usus, lalu dicuci dengan aquades dingin dan dikemas dalam kantung plastik dan segera disimpan pada suhu $-20{ }^{\circ} \mathrm{C}$. Pemilihan ikan bandeng fase post rigor berdasarkan pengamatan secara visual organoleptis sesuai SNI 01 2729-2006. Organ dalam masing-masing ditambahkan 
buffer Tris- $\mathrm{HCl}$ (Applicchem) pada $\mathrm{pH} 8,0$ dan dihomogenisasi menggunakan homogenizer (Nissei AM-3). Homogenat disentrifugasi menggunakan sentrifuse dingin (Sorvall) dengan kecepatan 7000xg selama 20 menit pada suhu $4{ }^{\circ} \mathrm{C}$. Supernatan ditambah $20 \mathrm{mM}$ Tris- $\mathrm{HCl} \mathrm{pH}$ 8,0. Ekstrak kolagenase kasar diendapkan menggunakan ammonium sulfat padat dengan tingkat kejenuhan yang bervariasi, yaitu antara $30 \%-80 \%(\mathrm{w} / \mathrm{v})$.

Karakterisasi kolagenase meliputi penentuan suhu optimum $10-80{ }^{\circ} \mathrm{C} ; \mathrm{pH}$ optimum 4,0-10,0; pengaruh ion logam $\left(\mathrm{NaCl}, \mathrm{CaCl}_{2}, \mathrm{BaCl}_{2}, \mathrm{MnCl}_{2}\right.$ dan $\mathrm{CoCl}_{2}$ ) (Merck) masing masing dengan konsentrasi 1 dan $5 \mathrm{mM}$; dan inhibitor EDTA (Merck), PMSF, dan pepstatin. Analisis meliputi uji aktivitas kolagenase berdasarkan metoda spektrofotometri (Moore dan Stein 1954, diacu dalam Kim et al. 2002) dan analisis protein menggunakan metoda Bradford (Bradford 1967). Substrat kolagen terbuat dari kulit ikan bandeng. Satu unit aktivitas kolagenase didefinisikan sebagai jumlah enzim yang menyebabkan perubahan 1 $\mu$ mol substrat per menit pada $\mathrm{pH} \mathrm{8,0} \mathrm{dan}$ suhu $37^{\circ} \mathrm{C}$.

\section{HASIL DAN PEMBAHASAN}

Aktivitas kolagenase pada usus adalah sebesar 0,141 Unit/ml. Konsentrasi protein kolagenase tersebut adalah 0,785 $\mathrm{mg} / \mathrm{ml}$, atau aktivitas spesifiknya sebesar 0,178 Unit/mg. Aktivitas spesifik kolagenae ini lebih rendah daripada ekstrak kasar kolagenase dari pilorik kaeka ikan tuna (Thunnus thynnus) (Byun et al. 2002) dan organ dalam filefish (Novodon modestrus) (Kim et al. 2002).

Kolagenase diproduksi oleh sel-sel jenis sel stromal, sel ephitel, makrofagus dan leukosit (Strenlicht \& Werb 2001). Usus adalah organ pencernaan yang terbangun dari sel-sel epitelium. Khojasteh et al. (2009) melaporkan bahwa secara histologi, struktur dinding sel usus halus pada ikan rainbow trout (Oncorhynchus mykiss) hampir sama dengan hewan vertebtara lain. Usus halus merupakan tempat sebagian pencernaan secara kimiawi terjadi. Sebagian besar enzim pencernaan yang bekerja pada usus disekresikan oleh pankreas melalui pankreatik duct. Lapisan tipis jaringan penghubung bersifat asam memisahkan mukosa dan sub mukosa. Pada permukaan mukosa terdapat villi, mengurangi lebar bagian depan dan ujung 
usus, dan epitelium yang membentuk lapisan tunggal kolom sel dengan basal nukleus yang mengandung nukleus, garis apical brush dan sitoplasma asidofilik. Kolagenase dari usus ini selanjutnya digunakan oleh organ-organ tertentu yang memerlukannya.

Penambahan ammonium sulfat pada ekstrak kasar menghasilkan endapan dan supernatan, yang masing-masing diuji aktivitas kolagenasenya. Hasil uji aktivitas terhadap hasil pengendapan diperoleh aktivitas tertinggi terdapat pada endapan dengan penambahan $70 \%(\mathrm{w} / \mathrm{v})$ tingkat kejenuhan $\mathrm{NH}_{4}\left(\mathrm{SO}_{4}\right)_{2}$, yaitu sebesar 0,496 Unit/ml dengan konsentrasi protein sebesar $1,185 \mathrm{mg} / \mathrm{ml}$, dan aktivitas spesifiknya 35,42 Unit/mg. Meningkatnya aktivitas enzim pada endapan hingga penambahan ammonium sulfat $\quad 70 \%$ disebabkan berkurangnya pengotor, seperti non protein (karbohidrat), protein non enzim dan lainlain (Suhartono 1989). Hasil uji aktivitas kolagenase pada endapan dan supernatan larutan enzim kolagenase yang ditambah dengan $\mathrm{NH}_{4}\left(\mathrm{SO}_{4}\right)_{2}$ dalam berbagai tingkat kejenuhannya disajikan pada Gambar 1.

Aktivitas kolagenase pada konsentrasi ammonium sulfat tingkat kejenuhan $80 \%$ menurun. Penurunan ini disebabkan karena ammonium sulfat tidak bersifat buffer dan dapat membebaskan ammonia, sehingga memungkinkan terjadinya kenaikan pH (Boyer 1993). Ammonium sulfat dipilih karena sifatnya yang mudah larut, murah dan umumnya tidak mempengaruhi struktur protein pada konsentrasi tertentu (Beynon \& Bond 2000). Akibatnya, aktivitas enzim menjadi menurun, karena aktivitasnya tersebut dipengaruhi oleh faktor lingkungan, seperti $\mathrm{pH}$. Aktivitas enzim menurun ketika $\mathrm{pH}$ lingkungan enzim melebihi $\mathrm{pH}$ optimumnya. 


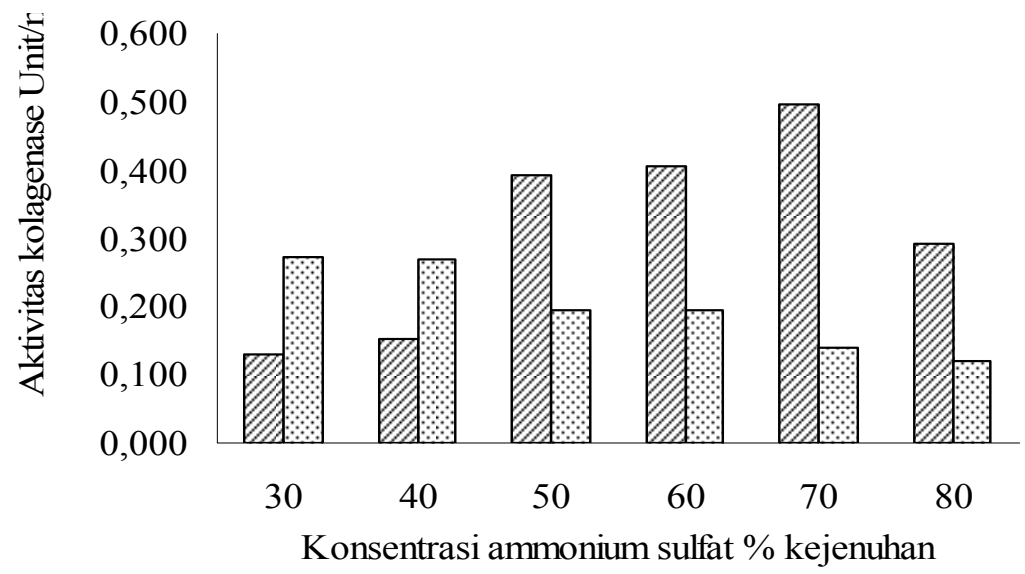

Gambar 1 Aktivitas kolagenase (Unit/ml) hasil pemisahan dengan pengendapan menggunakan $\mathrm{NH}_{4}\left(\mathrm{SO}_{4}\right)_{2}$. $\square$ endapan supernatan

Kim et al. (2002) mengendapkan ekstrak kasar kolagenase dari organ dalam ikan filefish (Novodon modestrus) menggunakan garam $\mathrm{NH}_{4}\left(\mathrm{SO}_{4}\right)_{2}$ secara bertingkat dari $30 \%$ hingga $80 \% \quad$ w/v tingkat kejenuhan. Park et al. (2002) menggunakan aseton dingin untuk mengendapkan ekstrak kasar kolagenase dari organ dalam ikan makarel (Scromber japanicus). Aktivitas spesifik pada pengendapan ekstrak kolagenase dari ikan filefish yaitu 145,34 Unit/mg, lebih besar dibandingkan aktivitas spesifik ekstrak kasar kolagense dari ikan makarel, yaitu 42,3 Unit/mg.

Tahapan proses semi purifikasi telah berjalan dengan baik hal ini dapat dilihat dengan peningkatan kelipatan pemurniannya. Kelipatan pemurnian kolagenase hasil semi purifikasi menggunakan ammonium sulfat $70 \%$ tingkat kejenuhan adalah 2,374 dari ekstrak kasarnya. Tingkat kelipatan pemurnian kolagenase hasil semi purifikasi kolagenase dari usus ikan bandeng disajikan pada Tabel 1 .

\begin{tabular}{lccrrrrrr}
\hline Tahapan & $\begin{array}{l}\text { Volume } \\
(\mathrm{ml})\end{array}$ & $\begin{array}{l}\text { Aktvitas } \\
\text { enzim } \\
\text { Unit/ml }\end{array}$ & $\begin{array}{l}\text { Aktivitas } \\
(\mathrm{U})\end{array}$ & $\begin{array}{l}\text { Konsentrasi } \\
\text { protein } \\
(\mathrm{mg} / \mathrm{ml})\end{array}$ & $\begin{array}{l}\text { Protein } \\
(\mathrm{mg})\end{array}$ & $\begin{array}{l}\text { Aktivitas } \\
\text { spesifik U/mg }\end{array}$ & $\begin{array}{l}\text { Derajat } \\
\text { kemurnian }\end{array}$ & Yield \\
\hline $\begin{array}{l}\text { Ekstraksi } \\
\text { Hasil }\end{array}$ & 450 & 0,141 & 63 & 0,785 & 353,25 & 0,178 & 1,00 & 100,00 \\
$\begin{array}{l}\text { pengendapan } \\
70 \% \text { ZA }\end{array}$ & 45 & 0,496 & 2,32 & 1,185 & 53,325 & 0,419 & 2,347 & 35,42 \\
\hline
\end{tabular}


Suhu optimum kolagenase yang diperoleh adalah sebesar $50{ }^{\circ} \mathrm{C}$. Enzim pada umumnya mempunyai temperatur optimum seperti temperatur sel. Enzim memiliki aktivitas maksimum pada suhu tertentu, dan aktivitasnya meningkat seiring dengan peningkatan suhu hingga mencapai suhu optimum. Setelah kenaikan suhu lebih lanjut, akan menyebabkan aktivitas menurun (Pelezar \& Chan 1988). Suhu kolagenase ini lebih tinggi dari suhu optimum kolagenase yang ditemukan pada rainbow trout (Onchorinchus mykiss tail) yaitu $20{ }^{\circ} \mathrm{C}$. Pada spesies lain, seperti filefish (Novodon modestus) (Kim et al. 2002), mempunyai suhu optimum kolagenase $55{ }^{\circ} \mathrm{C}$. Sedangkan pada udang (Pandalus eous) suhu optimum kolagenase $40-45^{\circ} \mathrm{C}$.

Kondisi $\mathrm{pH}$ optimum kolagenase hasil pengendapan adalah $\mathrm{pH}$ 9. Nilai ini sesuai dengan pernyataan bahwa pada umumnya proteinase dari organ pencernaan hewan laut mempunyai sifat unik, yaitu energi aktivitas Arrhenius yang rendah, konstanta Michaelis-Menten tinggi, stabil pada suhu dingin, mempunyai temperatur optimum yang rendah, bersifat termostabil rendah, mempunyai $\mathrm{pH}$ optimum yang tinggi (Simpson 2000). Pada spesies yang lain, seperti ikan makarel (Scomber japanicus) (Park et al. 2002) dan ikan tuna (Thunnus thynnus) ( (Byun et al. 2002), kolagenase mempunyai $\mathrm{pH}$ optimum 7,5. Kolagenase lain, yaitu dari udang (Aoki et al. 2003) dan Daging ikan Pasific rockfish (Sebastes sp) (Brocho \& Haard 1995), mempunyai $\mathrm{pH}$ optimum 7,5-8,5. Sedangkan kolagenase dari Bacillus subtillus FS-2 (Nagano \& Kim 1999) mempunyai pH optimum 9,0.

Penambahan ion logam $\mathrm{Mn}^{2+} 1$ dan $5 \mathrm{mM}$ menurunkan aktivitas kolagenase hingga aktivitas relatifnya menjadi $83 \%$ dan $79 \%$. Penambahan $\mathrm{Co}^{2+} 1$ dan $5 \mathrm{mM}$ mengakibatkan kolagenase mengalami penurunan aktivitas hingga aktivitas relatifnya menjadi $62 \%$ dan $61 \%$. Penambahan ion $\mathrm{Ca}^{2+}$ pada konsentrasi 1 dan $5 \mathrm{mM}$ dapat meningkatkan aktivitas relatif kolagenase hingga $122 \%$ dan $115 \%$. Pada penambahan $\mathrm{Na}^{+} 1 \mathrm{mM}$ aktivitas relatifnya menjadi $115 \%$ dan penambahan ion $\mathrm{Na}^{+}$hingga aktivitas relatifnya menjadi 130\%. Byun et al. (2002) melaporkan bahwa kolagenase pada pilorik kaeka tuna (Thunnus thynnus), dapat ditingkatkan aktivitasnya dengan penambahan ion $\mathrm{Na}^{+}$, $\mathrm{Mg}^{2+}, \mathrm{Ca}^{2+}, \mathrm{Mn}^{2+}$ dan $\mathrm{Ba}^{2+}$, tetapi dihambat dengan kuat oleh $\mathrm{Zn}^{2+}, \mathrm{Hg}^{2+}$ dan $\mathrm{Cu}^{2+}$. 
Kolagenase hasil pengendapan, pada $\mathrm{pH}$ netral mendekati basa (Kim et al. penghambatan terhadap PMSF $1 \mathrm{mM}$ dan 5 2008).

mM mencapai $30 \%$ dan $26 \%$. Tidak ada penghambatan yang berarti terhadap KESIMPULAN aktivitas kolagenase ketika ditambahkan EDTA 1 dan $5 \mathrm{mM}$. Aktivitas relatif kolagenase setelap penambahan EDTA adalah sebesar 93-96\%. Park et al. (2002) melaporkan kolagenase dari organ dalam Scomber japanicus digolongkan dalam serin protease, dapat dihambat oleh PMSF 1,0 $\mathrm{mM}$ dengan aktivitas relatif sebesar 46,8\%. Sedangkan menurut Aoki et al. (2003) penambahan PMSF $1 \mathrm{mM}$ dan 10 mM pada kolagenase dari udang (Pandalus eous) dapat menghambat hingga aktivitas relatifnya tinggal 5 dan $2 \%$.

Kolagenase stabil pada penyimpanan suhu $10-50{ }^{\circ} \mathrm{C}$. Kolagenase mengalami penurunan aktivitasnya setelah penyimpanan pada suhu $60{ }^{\circ} \mathrm{C}$. Enzimenzim dari organ pencernaan hewan laut mempunyai sifat bersifat termostabil rendah (Simpson 2000). Kolagenase pada pH 3-4 mempunyai aktivitas yang rendah. Kolagenase mempunyai aktivitas yang masih tinggi pada $\mathrm{pH}$ 6-11. Aktivitas tertinggi kolagenase stabil pada $\mathrm{pH}$ 8-9. Proteinase dari ikan mempunyai sifat stabil

\section{Ucapan Terimakasih}

Penelitian ini sebagian dibiayai oleh Dana Hibah Bersaing Batch DP2M-Ditjen DiktiDEPDIKNAS atas nama Dr. Tati Nurhayati, S.Pi, M.Si. 


\section{DAFTAR PUSTAKA}

Aoki H, Ahsan MN, Matsuo K, Hagiwara T, Watanabe S. 2003. Purification and characterization of collagenolytic proteases from the hepatopancreas of northern shrimp (Pandalus eous). $\underline{J}$ Agric Food Chem. 51:777-83.

[BPPT] Badan Pengkajian dan Penerapan Teknologi. 2003. Seminar Industri Enzim dan Bioteknologi. Jakarta: Humas BPPT. http://www.bppt.go.id/ index. php? option $\quad=$ com_ content $\&$ task=view\&id=1549\&Itemid $=30$.

Beynon RJ, Bond JS. 2001. Proteolisis Enzymes: a Practical Approach. New York: Oxford University Press.

Bradford MM. 1967. A rapid and sensitive method for quantification of microgram quantities of protein utilizing the principle of protein dye binding. Anal biochem 72: 234-254

Boyer RF. 1993. Modern Experimental Biochemistry. $2^{\text {nd }}$ ed. Redwoodcity. California: The
Benjamin/Cummings Publishing Co. Inc.

Byun HG, Park JP, Sung NI, Kim SK. 2002. Purification and characterization of a serine proteinase from the tuna piloric caeca. J Food Biochem. 26: 479494.

Clucas IJ dan Ward AR. 1996. PostHarvest Fisheries Development: A Guide to Handling, Preservation, Processing and Quality. Chanatam Maritime, UK: Natural Resources Institute.

[Ditjen Perikanan Budidaya]. 2007. Kebijakan dan program prioritas tahun 2008. Di dalam Rakornas Departemen Kelautan dan Perikanan tahun 2007. Jakarta: Departemen Kelautan dan Perikanan.

Fentiana N. 2009. Pengaruh enzim protease jeroan ikan bandeng (Channos channos Forskal) pada proses kemunduran mutu. [skripsi]. Bogor: Departemen Teknologi Hasil Perairan. Institut Pertanian Bogor. 
Hultmann L, Rustad T. 2004. Iced storage of Atlantic salmon (Salmo salar)effects on endogeneus enzymes and their impact on muscle proteins and texture. J Food Chemistry. 87: 3141

Hultmann L. 2003. Endogenous proteolytic enzymes - Studies of their impact on fish muscle proteins and texture [thesis]. Norwegian: Faculty of Natural Sciences and Technology. Department of Biotechnology. Norwegian NTNU.

Kim SK, Park PJ, Kim JB dan Sahidi F. $2002 . \quad$ Purification and characterization of a collagenolytic protease from filefish (Novodon modestrus). J. Biochem Mol Bio 35: 165-171.

Kim SK, Mendis E, Shahidi F. 2008. Marine Fisheries By-Products as Potencial Nutraceuticals:Overview. Di dalam Shahidi F, editor. Marine Nutraceuticals and Funcional Food. Boca Raton: CRC Press.

Lopez MD, Carreno LG. 2000. Applications of Fish and Shellfish Enzymes in Food and Feed Products. Di dalam Haard NF dan Simpson BK, editor. Seafood Enzymes Utilization and Influence on Postharvest Seafood Quality. New York: Marcel Dekker. Inc. hlm: 571-618.

Moore S, Stein W. 1954. A modified ninhydrin reagent for the photometric determination of amino acids and related compounds. $J$.
Biol. Chem. 211, 907-913. Di dalam Kim SK, Park PJ, Kim JB dan Sahidi F. 2002. Purification and characterization of a collagenolytic protease from filefish (Novodon modestrus). J. Biochem Mol Bio. 35: 165-171.

Nagano H, To KA. 1999. Purification of collagenase and specificity of its releted enzyme from Bacillus subtillis FS-2. Bioschi, Biotechnol, Biochem. 63: 181-183.

Park PJ. Lee SH, Byun HG, Kim SH, Kim SK. 2002. Purification and characterization of a collagenase from the Mackarel, Scomber japonicus. J Biochem Mol Bio. 35: 576-582.

Rilley KM, Herman IM. 2005. Collagenase promotes the celuller responses to injury and wound healing in vivo. $J$ Burns and Wounds. 4:112-124.

Simpson BK. 2000. Digestives Proteinases from Marine Animals. Di dalam: Haard NF dan Simpson BK, editor. Seafood Enzymes Utilization and Influence on Postharvest Seafood Quality. New York : Marcel Dekker. Inc. hlm 191-207.

USDA SR-21. (2009). Fish, milkfish, raw. http://www.nutritiondata.com/facts/ finfish -and-shellfishproducts/4079/2 [6 Desember 2009]. 